\title{
Primary epithelioid hemangioendothelioma of the penis: a case report and literature review
}

\author{
Alberto Artiles Medina ${ }^{1,2}$, Agustín Fraile Poblador ${ }^{1,2}$, Manuel Hevia Palacios ${ }^{1,2}$, Irene Carretero Barrio ${ }^{3}$, \\ María Eugenia Reguero ${ }^{3}$, Rafael Rodríguez-Patrón Rodríguez ${ }^{1,2}$, Francisco Javier Burgos Revilla ${ }^{1,2}$ \\ ${ }^{1}$ Department of Urology, Hospital Universitario Ramón y Cajal, Madrid, Spain; ${ }^{2}$ Instituto Ramón y Cajal de Investigación Sanitaria (IRYCIS), \\ Madrid, University of Alcalá, Madrid, Spain; ${ }^{3}$ Department of Pathology, Hospital Universitario Ramón y Cajal, Madrid, Spain \\ Correspondence to: Dr. Alberto Artiles Medina. Department of Urology, Hospital Universitario Ramón y Cajal, Madrid, Spain. Email: \\ alberc.artiles@gmail.com.
}

\begin{abstract}
Epithelioid hemangioendothelioma (EHE) is a rare vascular tumour with an intermediate behaviour between benign hemangioma and malignant angiosarcoma. There is scarce data on the penile EHE's management and its natural history, as our knowledge is based on few reported cases with a short follow-up period. We present a case report and conducted a literature review, including 17 cases. The relevance of this case report derives from the need for better clinical characterization of patients with penile EHE and the importance of defining the outcomes. We report the case of a 53-year-old male with a 1-year history of sleep-related painful erections. Imaging techniques showed a well-defined hypoechoic and hypervascular solid nodule on the dorsal aspect of the penis. It was surgically removed, and the histopathological study revealed a low-risk EHE of the penis. Follow-up magnetic resonance imaging (MRI) and computed tomography did not demonstrate local recurrence nor metastases. According to the literature review, most of the patients were in their fifth and sixth decades of life at the time of diagnosis and lesions were usually located in the glans. The most common clinical presentation was as a painful mass. Follow-up period ranged from 2 months to 5 years. Three patients showed systemic metastases, two of which died due to cancer. The conclusions from the literature review are limited by the reduced number of cases and the short follow-up. This case report highlights the importance of understanding the diagnosis and treatment of this type of rare non-squamous malignant tumours of the penis. Penile EHE is a malignant vascular tumour that is very rare in this location. The best treatment is local excision, with re-excision or intraoperative margins assessment. Occasionally, systemic chemotherapy and radiation therapy can be useful. There is consensus on the importance of very strict follow-up of these patients.
\end{abstract}

Keywords: Epithelioid hemangioendothelioma (EHE); penile neoplasms; penis; penile cancer; case report

Submitted Apr 03, 2021. Accepted for publication Jul 08, 2021.

doi: $10.21037 /$ tau-21-277

View this article at: https://dx.doi.org/10.21037/tau-21-277

\section{Introduction}

Epithelioid vascular tumours are rare vascular neoplasms. They are a subtype of mesenchymal tumours, defined by their epithelioid morphology, which differentiates them from other vascular tumours (1). Epithelioid hemangioendothelioma (EHE) is an uncommon vascular tumour that was first described in 1975 by Dail and Liebow in the lung as an aggressive bronchoalveolar cell carcinoma (2). EHE demonstrates an intermediate behaviour between benign hemangioma and malignant angiosarcoma. It can occur in soft tissues, bones and visceral organs, but also as a primary tumour of the blood vessels.

Non-squamous cell carcinoma primary malignancies represent fewer than $5 \%$ of penile cancers. Soft tissue malignancies of the penis are mainly vascular tumours, such as Kaposi sarcoma, EHE and angiosarcoma, followed by other sarcomas like rhabdomyosarcoma and 
leiomyosarcoma (3).

There is a scarcity of published data on penile EHE's management and its natural history. Until 2015, 17 cases of penile EHE have been reported in the literature (4). Of these cases, two presented with metastasis and two with multifocal penile EHE lesions. Furthermore, the benign type of the spectrum, the penile epithelioid hemangioma (EH), is also a very rare vascular neoplasm. Until 2015, only 28 cases in the literature have been reported (5).

To date, reported characteristics of EHE are based on this small number of published cases. The rates of local recurrences, metastases and mortality of this tumour are $10 \%, 20-30 \%$ and $15 \%$, respectively. Treatment decisions should be based on pathological findings. Treatment options include excision or multimodal therapy (1).

We reported the case of an EHE involving the penis in a 53-year-old male treated with complete resection. This case report contributes to widen our knowledge of this rare tumour and the literature review offers an update on its management.

\section{Literature review}

We carried out a literature review in PubMed (MEDLINE) of reported cases and analysed therapeutic arsenal (surgery, antitumour drugs and radiation) used in the treatment of these unusual tumours.

The search strategy was as follows: ("Hemangioendothelioma, Epithelioid"[Mesh] OR "Hemangioendothelioma"[Title/abstract]) AND ("Penis"[Mesh] OR "penile"[title/abstract] OR "Penile Neoplasms"[Mesh]). Inclusion criteria were: histologically confirmed cases of penile EHE, and no language or temporal restrictions were applied. Two authors independently reviewed the literature and decided which case reports to include in this study. We summarized the case reports in Table 1, and we extracted the most important aspects: age, clinical presentation, size and location, management, follow-up period, local recurrence or metastases, and survival time.

We present the following case in accordance with the CARE reporting checklist (available at https://dx.doi. org/10.21037/tau-21-277).

\section{Case presentation}

A 53-year-old patient with a past medical history of hypertension presented to the urology department for penile pain during erections. He denied any penile injury or trauma. He complained of sleep-related painful erections causing sleep disruption that affected his quality of life. He was also experiencing lump sensation and progressive curvature of the penis for one year. Previously, a consultant urologist had diagnosed acute phase of Peyronie's disease. On physical examination there was a dorsal nodule at the root of the penis of $1 \mathrm{~cm}$ in size, that was not clearly arising from or depending on the tunica albuginea.

A penile colour Doppler ultrasonography was performed, and it showed a hypervascular nodule in the dorsal aspect of the cavernous body, lateralized to the right, without calcifications, measuring $13 \times 4 \times 3 \mathrm{~mm}$ (Figure 1A,1B). The magnetic resonance imaging (MRI) demonstrated a nodule on the dorsal aspect of the penis (Figure 1C).

As penile neoplastic lesion was suspected based on clinical and radiological findings, the lesion was surgically removed with 5 -mm surgical excision margins. The lesion was firmly attached to the penile dorsal nerve. Because this is the sensory nerve for the glans and penis, a careful dissection technique was performed in order to avoid nerve injury. Furthermore, we tried to minimize the use of bipolar cautery to avoid nerve trauma.

Gross examination of the specimen revealed a soft tissue mass, measuring $2 \mathrm{~cm}$ in its greater dimension. On microscopic examination, although focally surrounded by a thin membrane, the tumour showed an infiltrative pattern, with a small focus of necrosis. It was formed by a densely cellular neoplastic proliferation, with cells arranged in cords at the periphery of the lesion and solid areas in the centre, where we found the remains of a vessel wall (Figure 2A-2C). The cells had an epithelioid appearance, with large eosinophilic cytoplasm and frequent intracytoplasmic vacuoles, some of them containing red blood cells. The nuclei were ovoid and vesicular, with variable size and occasional prominent nucleoli and atypia. It was accompanied by a mild intratumoral inflammatory infiltrate, with lymphocytes and eosinophils. Mitotic activity was up to 2 mitoses per 10 high-power fields.

The immunohistochemistry showed intense membrane positivity for CD31 (Figure 2D) and nuclear positivity for FLI-1 and ERG. It had a patchy expression of CKAE1AE3. The tumour was negative against S100, HMB45, MELAN-A and D2-40. Smooth muscle actin highlighted the muscle remains in the centre of the lesion, which could represent a vessel wall. The proliferation index (Ki67) was $7 \%$.

The histopathological analysis revealed a low-risk EHE 
Table 1 Case reports of EHE of the penis

\begin{tabular}{|c|c|c|c|c|c|c|c|c|}
\hline $\begin{array}{l}\text { Case (author } \\
\text { and year of } \\
\text { publication) }\end{array}$ & $\begin{array}{l}\text { Age of the } \\
\text { patient }\end{array}$ & Clinical presentation & Size $(\mathrm{cm})$ and location & Management & $\begin{array}{l}\text { Low or high risk } \\
\text { (published in } \\
2008, \\
\text { Deyrup et al.) }\end{array}$ & $\begin{array}{l}\text { Follow-up } \\
\text { period (years) }\end{array}$ & $\begin{array}{l}\text { Local recurrence or } \\
\text { metastases }\end{array}$ & Survival time \\
\hline $\begin{array}{l}\text { Zhang et al. } 2015 \\
\text { (6) }\end{array}$ & 62 yo & Penile mass with pain & $\begin{array}{l}4 \mathrm{~cm} \\
\text { Root of the penis }\end{array}$ & Phallectomy & Not available & 2 months & Not available & 2 months \\
\hline $\begin{array}{l}\text { Yoshi-Hiro et al. } \\
2015 \text { (7) }\end{array}$ & 43 yo & Painful nodules & Three nodules with a few millimeters in diameter & Not available & Not available & Not available & Not available & Not available \\
\hline $\begin{array}{l}\text { Darshan et al. } \\
2014(8)\end{array}$ & 59 yo & $\begin{array}{l}\text { A painful, enlarging lump on the base of his penis } \\
\text { for } 5 \text { months } \\
\text { The patient was misdiagnosed with penile vein } \\
\text { thrombosis versus atypical Peyronie's disease }\end{array}$ & $\begin{array}{l}\text { A } 1.25 \mathrm{~cm} \times 0.3 \mathrm{~cm} \text { vascular mass superficial to the } \\
\text { tunica of the dorsal penis }\end{array}$ & Complete resection & Low-risk EHE & 9 months & $\begin{array}{l}\text { MRI of the pelvis at } \\
3 \text { months and } 9 \text { months did } \\
\text { not demonstrate recurrent } \\
\text { or metastatic disease }\end{array}$ & $\begin{array}{l}\text { At least } \\
9 \text { months }\end{array}$ \\
\hline $\begin{array}{l}\text { Abdalla et al. } \\
2013 \text { (9) }\end{array}$ & $1 \mathrm{mo}$ & $\begin{array}{l}\text { Swelling at the tip of the penis and burning } \\
\text { micturition }\end{array}$ & $\begin{array}{l}\text { A fungating } 6 \text { by } 8 \mathrm{~cm} \text { mass } \\
\text { At the distal part of the penis }\end{array}$ & Amputation and reconstruction of the penis & Low-grade EHE & Not available & Not available & Not available \\
\hline $\begin{array}{l}\text { Carballo et al. } \\
2012 \text { (10) }\end{array}$ & 63 уо & $\begin{array}{l}1 \mathrm{~cm}-\text { size nodule, painful, bluish, located in the } \\
\text { glans }\end{array}$ & $\begin{array}{l}1 \mathrm{~cm} \\
\text { Glans }\end{array}$ & The new lesion was surgically removed with intraoperative margins assessment & Not available & 6 months & Free & $\begin{array}{l}\text { At least } \\
6 \text { months }\end{array}$ \\
\hline $\begin{array}{l}\text { Shin et al. } 2010 \\
\text { (11) }\end{array}$ & 28 yo & Asymptomatic subdermal glanular lesion & Not available & Partial penectomy & Not available & Not available & Not available & Not available \\
\hline $\begin{array}{l}\text { Wedmid et al. } \\
2009 \text { (1) }\end{array}$ & 48 yo & Several violaceous, indurated, subcutaneous lesions & $\begin{array}{l}\text { A } 1.5 \mathrm{~cm} \text { plaque-like lesion } \\
\text { Located deep within the corporal body near the } \\
\text { distal shaft }\end{array}$ & $\begin{array}{l}\text { A multimodal approach (systemic chemotherapy with eight cycles of liposomal } \\
\text { doxorubicin + adjuvant radiation therapy) }\end{array}$ & High risk EFE & 18 months & $\begin{array}{l}\text { Free of any evidence of local } \\
\text { or metastatic progression }\end{array}$ & $\begin{array}{l}\text { At least } \\
18 \text { months }\end{array}$ \\
\hline $\begin{array}{l}\text { Zastrow et al. } \\
2008 \text { (12) }\end{array}$ & 58 yo & Indolent nodule $7 \mathrm{~mm}$ in diameter & $\begin{array}{l}7 \mathrm{~mm} \\
\text { On the ventral aspect of the glans penis }\end{array}$ & $\begin{array}{l}\text { Local excision of the tumour } \\
\text { Two weeks later we performed a second excision of the remaining tumour }\end{array}$ & Not available & 52 months & Not available & Not available \\
\hline $\begin{array}{l}\text { Wen et al. } 2004 \\
\text { (14) }\end{array}$ & 58 yo & $\begin{array}{l}\text { 6-month history of penile pruritus associated with } \\
\text { a painful progressive firmness (the patient was } \\
\text { misdiagnosed with Peyronie's disease) }\end{array}$ & $\begin{array}{l}\text { A 2-cm necrotic ulcer was also noted on the glans } \\
\text { penis }\end{array}$ & $\begin{array}{l}\text { Because the metastatic workup revealed hepatic and pulmonary lesions, } \\
\text { penectomy was not performed and the patient was treated with paclitaxel }\end{array}$ & Not available & 13 months & $\begin{array}{l}\text { He died of progressive } \\
\text { tumour spread }\end{array}$ & 13 months \\
\hline $\begin{array}{l}\text { Kamat et al. } 2004 \\
\text { (15) }\end{array}$ & 46 yo & $\begin{array}{l}\text { Skin nodules developed in the subcutaneous } \\
\text { lymphatics of the penis as well as the groin }\end{array}$ & $\begin{array}{l}1 \text { to } 2 \mathrm{~cm} \text { node } \\
\text { Medial to the right femoral vessels }\end{array}$ & $\begin{array}{l}\text { Resection of the nodules and inguinal nodes in the left groin, and en bloc } \\
\text { resection of the skin and subcutaneous tissue of the penis and upper scrotum } \\
\text { Interferon-3 times weekly for } 1 \text { year }\end{array}$ & Not available & 65 months & $\begin{array}{l}\text { No evidence of recurrent } \\
\text { disease }\end{array}$ & $\begin{array}{l}\text { At least } \\
65 \text { months }\end{array}$ \\
\hline $\begin{array}{l}\text { Gutiérrez-García } \\
\text { et al. } 2004 \text { (16) }\end{array}$ & 64 yo & Painful erections for 6 months & $\begin{array}{l}1 \mathrm{~cm} \\
\text { Dorsal aspect of penis }\end{array}$ & Local excision of the tumour with a cut-off of normal tissue & Low risk & 1 year & Free & At least one year \\
\hline $\begin{array}{l}\text { Haidar et al. } 1995 \\
(17)\end{array}$ & 60 yo & $\begin{array}{l}\text { A nodular swelling of the penile shaft of unknown } \\
\text { duration }\end{array}$ & Nodular mass measuring $7 \times 6 \times 3 \mathrm{~mm}$ & A complete excision with adequate margins & Not available & Not available & Not available & Not available \\
\hline $\begin{array}{l}\text { Elhosseiny et al. } \\
1986 \text { (18) }\end{array}$ & 60 yo & A painless mass of one-year duration & $\begin{array}{l}\text { A firm } 2.5 \text { by } 2-\mathrm{cm} \text { nodule over the midportion of the } \\
\text { dorsal aspect of the shaft of the penis }\end{array}$ & Removal by simple excision with a $0.5 \mathrm{~cm}$ cuff of fibroconnective tissue & Not available & Not available & Not available & Not available \\
\hline $\begin{array}{l}\text { Deutsch et al. } \\
1973(19)\end{array}$ & 17 yo & $\begin{array}{l}\text { A mass in the left scrotum on a routine physical } \\
\text { examination }\end{array}$ & $\begin{array}{l}5 \times 3.5 \times 1 \mathrm{~cm} \\
\text { It was involving the corpora cavernosa and attached } \\
\text { to the urethra }\end{array}$ & $\begin{array}{l}\text { Excision and postoperative irradiation to the primary site. Systemic } \\
\text { chemotherapy and radiotherapy to the thoracic spine was administered in the } \\
\text { belief that the patient had bone metastases }\end{array}$ & Not available & 5 years & $\begin{array}{l}\text { Distant metastases in three } \\
\text { different organ systems: } \\
\text { pulmonary, osseous, and } \\
\text { spinal cord }\end{array}$ & Not available \\
\hline $\begin{array}{l}\text { Barnett et al. } \\
1960 \text { (20) }\end{array}$ & 41 yo & Perineal pain & $\begin{array}{l}\text { An ill-defined mass was felt on rectal examination } \\
\text { lateral to and proximal to the prostate gland and } \\
\text { attached to the ischium }\end{array}$ & En bloc removal & Not available & 6 months & $\begin{array}{l}\text { No evidence of recurrence } \\
\text { or metastases }\end{array}$ & $\begin{array}{l}\text { At least } \\
6 \text { months }\end{array}$ \\
\hline $\begin{array}{l}\text { Varney et al. } \\
1955(21)\end{array}$ & 54 yo & A 3-day history of painless hematuria & $\begin{array}{l}1 \mathrm{~cm} \text { in diameter, in the floor of the anterior urethra } \\
\text { approximately } 6 \mathrm{~cm} \text { proximal to the urethral meatus }\end{array}$ & $\begin{array}{l}\text { Excision with the resectoscope loop } \\
\text { After that, irradiation therapy to the left ischium }\end{array}$ & Not available & 2 years & Ischium lesion & At least 2 years \\
\hline
\end{tabular}

EHE, epithelioid hemangioendothelioma. yo, years old; mo, month old. 

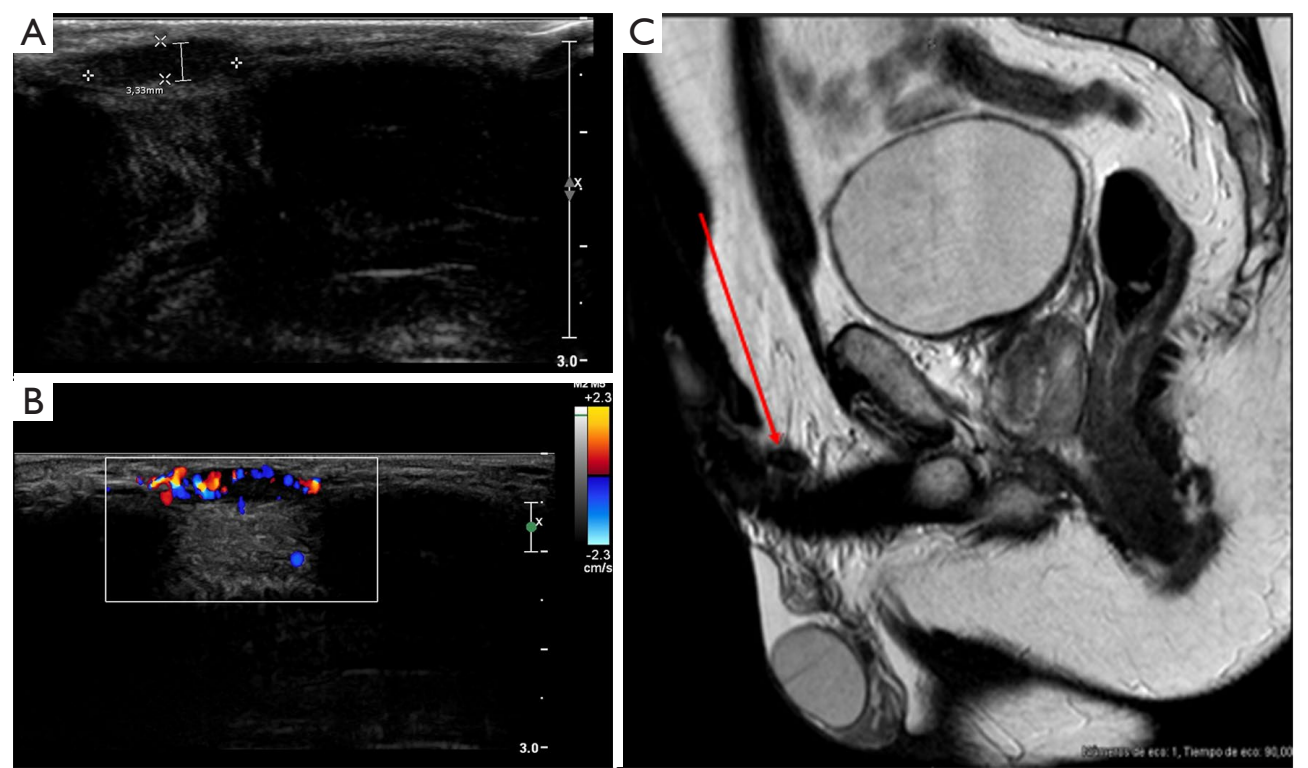

Figure 1 Diagnostic imaging findings on presentation. (A) A transverse ultrasound scan of the dorsal aspect of the midshaft of the penis shows the two paired corpora cavernosa a well-defined hypoechoic solid nodule, located centrally. (B) Doppler images show a hypervascular hypoechoic mass. (C) MRI T2 sagittal, revealing a small nodule (red arrow) in a corpus cavernosum, on the dorsal aspect of the penis.

of the penis. Subsequent penile MRI did not detect local recurrence two and six months after complete resection.

The staging computed tomography (CT) scan was negative for metastatic disease. This case was presented in the uro-oncologic multidisciplinary team meeting and a strict surveillance protocol was chosen.

\section{Etbics}

All procedures performed in studies involving human participants were in accordance with the ethical standards of the institutional and/or national research committee(s) and with the Helsinki Declaration (as revised in 2013). Written informed consent was obtained from the patient for publication of this study and any accompanying images.

\section{Discussion}

The term "epithelioid hemangioendothelioma" was introduced in 1982 by Weiss and Enzinger to describe a vascular tumour of bone and soft tissue showing features between hemangioma and angiosarcoma (16). EHE was re-classified from the benign tumour (WHO 2007) to a malignant one (2016). The estimated prevalence of EHE is less than one in 1 million (2).
There is very little evidence for the management of penile EHE, because it is based on few individual case reports, with a short follow-up period.

The literature review revealed seventeen cases. Patient age range was one month old to 64 years, but most of the patients were in their fifth and sixth decades of life at time of diagnosis. The size of the lesion was variable, ranging from 0.7 to $6 \mathrm{~cm}$, and most of them were located in the glans. The most common clinical presentation was as a painful mass. Local excision of the tumour ( \pm re-excision) was the most frequent treatment. Three patients needed adjuvant radiation therapy (RT) and five needed systemic chemotherapy (paclitaxel, doxorubicin or interferon). Immunohistochemically, 8 cases were tested and positive for at least one endothelial marker (CD31, CD34, factor VIII). Follow-up period ranges from 2 months to 5 years. Three cases showed systemic metastases and of them, two patients died due to cancer. We present the case of an EHE in a patient in the fifth decade of life, with a size of $13 \mathrm{~mm}$ and debuting with painful erections.

Patel et al. (8), Gharajeh et al. (13) and Wen et al. (14) published examples of EHE mimicking Peyronie's disease, penile thrombophlebitis or priapism. Otherwise, Zhang et al. (6) published the case of a primary pulmonary EHE with penile metastases. Kamat et al. (15) reported a case 

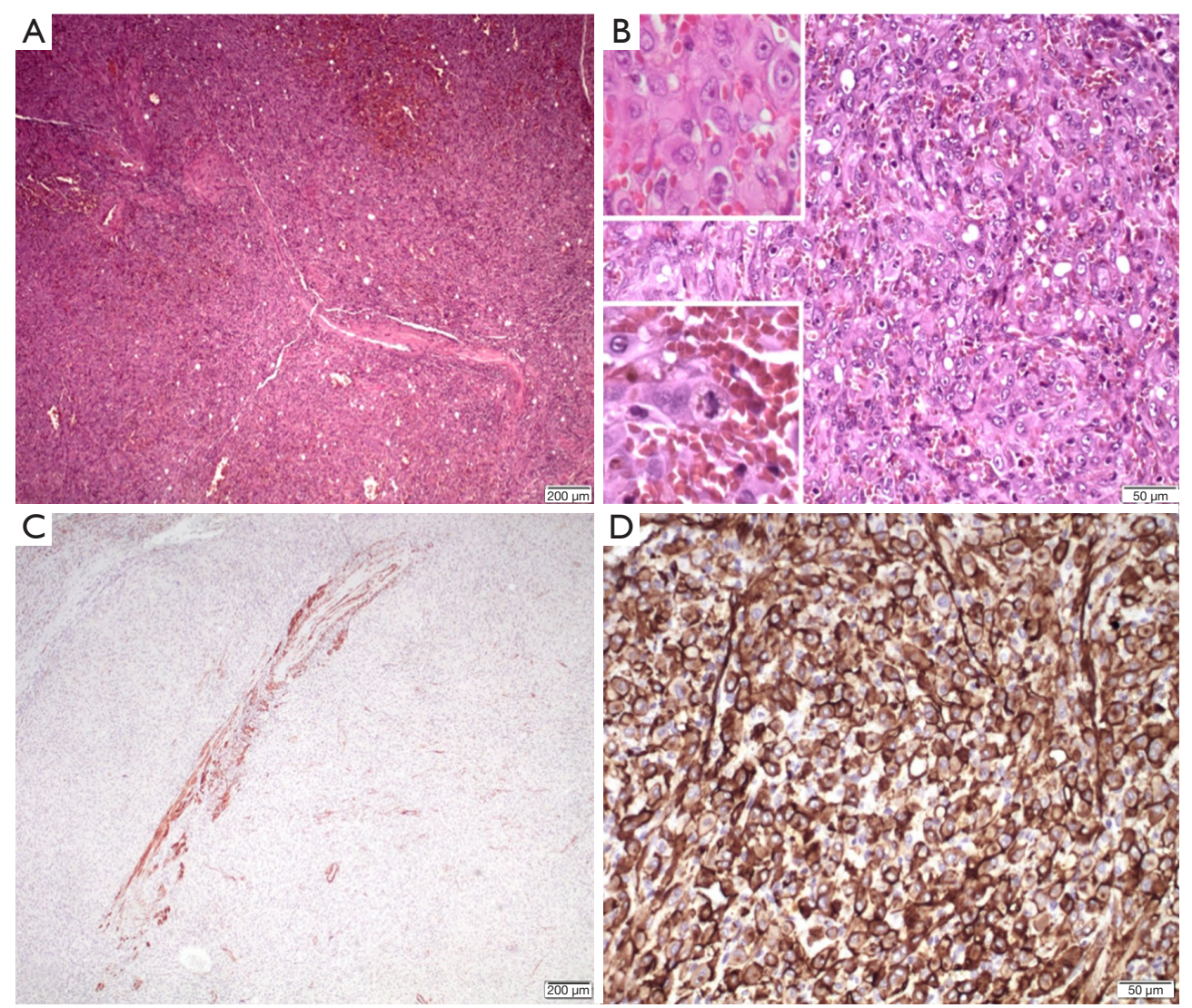

Figure 2 Pathology of the tumour. (A) Haematoxylin eosin (scale bar $=200 \mu \mathrm{m}$ ). The tumour is composed of a highly cellular neoplastic proliferation with cells arranged in solid areas. In the centre of the image there are the remains of a vessel wall. (B) Haematoxylin eosin (scale bar $=50 \mu \mathrm{m})$. The tumour cells have an epithelioid appearance, with eosinophilic cytoplasm, oval nuclei and prominent nucleoli. There are intracytoplasmic vacuoles, some of them containing red blood cells (upper inset). We found up to 2 mitoses in 10 high power fields (lower inset). (C) Smooth muscle actin antibody staining (scale bar $=200 \mu \mathrm{m}$ ). There are smooth muscle fibbers in the middle of the lesion, which may represent a vessel wall. (D) CD31 antibody staining (scale bar =50 $\mu \mathrm{m}$ ). Diffuse membrane positivity on tumour cell.

of metastatic EHE successfully treated with primary resection and systemic chemotherapy with interferon alpha. Furthermore, Zastrow et al. (12) presented a case of recurrent multifocal penis EHE.

EHE of the penis should be considered in the differential diagnosis of patients presenting with painful penile lumps. In addition, it can be misdiagnosed with as Peyronie's disease or penile thrombophlebitis. A thorough histological and immunohistochemical examination is necessary to make the diagnosis. The differential histopathological diagnosis of EHE includes EH and epithelioid angiosarcoma (13). In our case, the patient was initially misdiagnosed with the acute phase of Peyronie's disease, as pain may occur without an erection, caused by inflammation in the area of the developing plaques.
Mentzel et al. published a series of $30 \mathrm{EHE}$ of soft tissues and they showed a median age of 50 years and female predominance. Five tumours were located in anogenital regions. With a median follow-up of 36 months, local recurrence was observed in three cases and systemic metastases in five cases. Finally, four patients (17\%) died due to cancer. They conclude that more aggressive histologic features (striking nuclear atypia or more than two mitoses per 10 high-power fields) tended to be related to worse prognosis (22). The mitotic rate in our case was low, that is, $\leq 2$ mitoses per 10 high-power fields. Therefore, it was classified as a low-grade EHE.

Because of its rarity, there is no standard treatment. According to Sardaro et al. (2), in a study of pulmonary EHE, when the lesions are small and limited in number, 
some authors recommend surgical resection. Successful curative resection achieves good outcomes. The role of adjuvant chemotherapy and/or RT is ambiguous. Usually, RT after surgical resection is chosen for localized EHE, in order to control the residual disease given the recurrence of EHE, while chemotherapy is preferred in cases with widespread disease.

Limitations of this review are the scarcity of cases and short follow-up. These limitations prevent us from drawing strong conclusions.

This case report and the related literature review give some insights about the management of this rare tumour and may help clinicians recognize its clinical presentation. Nevertheless, it is crucial to improve future research and compile new reported cases to better establish the characteristics of EHE.

In conclusion, EHE is a malignant vascular tumour that rarely affects the penis. Local excision of the tumour, with re-excision or intraoperative margins assessment, is the best treatment. Systemic chemotherapy and RT can be used to treat locally advanced or widespread disease. Patients require a strict follow-up in order to detect early local recurrence.

\section{Acknowledgments}

Funding: None.

\section{Footnote}

Reporting Checklist: The authors have completed the CARE reporting checklist. Available at https://dx.doi. org/10.21037/tau-21-277

Peer Review File: Available at https://dx.doi.org/10.21037/ tau-21-277

Conflicts of Interest: All authors have completed the ICMJE uniform disclosure form (available at https://dx.doi. org/10.21037/tau-21-277). The authors have no conflicts of interest to declare.

Ethical Statement: The authors are accountable for all aspects of the work in ensuring that questions related to the accuracy or integrity of any part of the work are appropriately investigated and resolved. All procedures performed in studies involving human participants were in accordance with the ethical standards of the institutional and/or national research committee(s) and with the Helsinki Declaration (as revised in 2013). Written informed consent was obtained from the patient for publication of this study and any accompanying images.

Open Access Statement: This is an Open Access article distributed in accordance with the Creative Commons Attribution-NonCommercial-NoDerivs 4.0 International License (CC BY-NC-ND 4.0), which permits the noncommercial replication and distribution of the article with the strict proviso that no changes or edits are made and the original work is properly cited (including links to both the formal publication through the relevant DOI and the license). See: https://creativecommons.org/licenses/by-nc-nd/4.0/.

\section{References}

1. Wedmid A, Masterson TA, Maki RG, et al. A case of highrisk penile epithelioid hemangioendothelioma. Nat Rev Urol 2009;6:223-7.

2. Sardaro A, Bardoscia L, Petruzzelli MF, et al. Epithelioid hemangioendothelioma: an overview and update on a rare vascular tumor. Oncol Rev 2014;8:259.

3. Rajan S, Kumar V, Chaturvedi A, et al. Penile Sarcoma: Report of a Rare Malignancy. J Clin Diagn Res 2016;10:XD01-2.

4. Ciliberti MP, Caponio R, Pascali A, et al. A rare case of intravascular epithelioid hemangioendothelioma of the cephalic vein treated with surgery and postoperative radiation therapy: a case report and review of the literature. J Med Case Rep 2015;9:91.

5. Rajender A, Munarriz R, Phillips E. Penile epithelioid hemangioma: A case report. J Integr Nephrol Androl 2015;2:38.

6. Zhang K, Da J, Yao HJ, et al. Metastatic tumors of the penis: a report of 8 cases and review of the literature. Medicine (Baltimore) 2015;94:e132.

7. Ide YH, Tsukamoto Y, Ito T, et al. Penile pseudomyogenic hemangioendothelioma/epithelioid sarcoma-like hemangioendothelioma with a novel pattern of SERPINE1-FOSB fusion detected by RT-PCR--report of a case. Pathol Res Pract 2015;211:415-20.

8. Patel D, Redshaw J, Brant W, et al. Clinical, radiologic, and pathologic analysis of penile epithelioid hemangioendothelioma: A diagnostic and management dilemma. J Integr Nephrol Androl 2014;1:48.

9. Abdalla AA. Low grade penile epithelioid hemangioendothelioma in a one month old child. 
Available online: https:/www.researchgate.net/ publication/341119175_Low_grade_penile_epithelioid_ hemangioendothelioma_in_a_one_month_old_child

10. Carballo MP, Méndez J, Paes de Lima A, et al. Hemangioendotelioma epitelioide recidivante de pene. Rev Arg de Urol 2012;77:107-10.

11. Shin DH, Chen M, Niemeier LA. Primary epithelioid hemangioendothelioma of the kidney and penis. Can J Urol 2010;17:5480-2.

12. Zastrow S, Baretton GB, Wirth MP. Multifocal recurring epithelioid hemangioendothelioma of the penis. Urology 2008;71:351.e9-10.

13. Gharajeh A, Siemens DR, Isotalo PA, et al. Multifocal penile epithelioid hemangioendothelioma masquerading as superficial penile vein thrombosis. Urology 2006;68:673.e1-3.

14. Wen CC, Munarriz R, Goldstein I. Three-chamber priapism in a patient with primary epithelioid hemangioendothelioma of penis. Urology 2004;64:156-8.

15. Kamat AM, Plager C, Tamboli P, et al. Metastatic epithelioid hemangioendothelioma of the penis managed with surgery and interferon-alpha. J Urol

Cite this article as: Artiles Medina A, Fraile Poblador A, Hevia Palacios M, Carretero Barrio I, Reguero ME, Rodríguez-Patrón Rodríguez R, Burgos Revilla FJ. Primary epithelioid hemangioendothelioma of the penis: a case report and literature review. Transl Androl Urol 2021;10(9):3697-3703. doi: $10.21037 /$ tau-21-277
2004;171:1886-7.

16. Gutiérrez García R, Capdevila Hernández JM, Pinto Blázquez J, et al. Epithelioid hemangioendothelioma of penis. Actas Urol Esp 2004;28:771-3.

17. Haidar A, Batman P. Epithelioid haemangioendothelioma of the penile shaft. Br J Urol 1995;75:796-7.

18. Elhosseiny AA, Ramaswamy G, Healy RO. Epithelioid hemangioendothelioma of penis. Urology 1986;28:243-5.

19. Deutsch M, Leen RL, Mercado R Jr. Hemangioendothelioma of the penis with late appearing metastases: report of a case with review of the literature. J Surg Oncol 1973;5:27-34.

20. Barnett CP, Low JR. Hemangio-endothelioma of the corpus cavernosum penis: case report. J Urol 1960;83:160-2.

21. Varney DC. Malignant hemangio-endothelioma of the urethra: a case report. J Urol 1955;73:691-6.

22. Mentzel T, Beham A, Calonje E, et al. Epithelioid hemangioendothelioma of skin and soft tissues: clinicopathologic and immunohistochemical study of 30 cases. Am J Surg Pathol 1997;21:363-74. 